\title{
BAING YUSUF \\ (Ulama Central dalam Islamisasi di Purwakarta)
}

\author{
Ricko Andhitiyara \\ Mahasiswa Sejarah Kebudayaan Islam Program Pascasarjana UIN Sunan Gunung Djati Bandung \\ $\underline{\text { Ricoandy.ra@gmail.com }}$
}

\begin{abstract}
ABSTRAK
Di Indonesia, para ulama telah memainkan peranan yang sangat penting dan strategis. Mereka berperan bukan hanya dalam peningkatan spiritual umat saja, akan tetapi juga dalam mendobrak kekuasaan pemerintahan Kolonial. Sejarah menjadi saksi betapa ulama telah berjasa besar dalam perjuangan kemerdekaan. Bukan hanya itu, ulama juga memainkan peranan penting dalam kehidupan bermasyarakat dikarenakan mereka memiliki posisi sebagai pemimpin informal, guru, pembina, dan pengajar agama khususnya. Dimana disini masyarakat menganggap ulama adalah pewaris Nabi Muhammad SAW dan perantara mereka dalam memahami ajaran yang dibawa oleh Nabi Muhammad SAW. Islam memandang para ulama merupakan penerus jejak risalah dan contoh panutan untuk masyarakat guna selamat. Begitu pun dengan Syekh Baing Yusuf, beliau merupakan salah satu tokoh penyebar agama Islam di Purwakarta. Beliau telah berkelana ke Madagaskar dan melanjutkan perjalanannya ke Tanah Suci guna menuntut ilmu. Dalam beberapa sumber sejarah Purwakarta, disebutkan bahwa Baing Yusuf merupakan tokoh sentral dalam penyebaran dan pengembangan agama Islam yang terdapat di Purwakarta. Baing Yusuf merupakan guru dari pendiri Pondok Pesantren Sempur ${ }^{1}$, K.H. Bakri (masyarakat Purwakarta dan khususnya masyarakat setempat lebih mengenal dengan panggilan Mama Sempur²).
\end{abstract}

Kata Kunci: Islamisasi, Baing Yusuf, Purwakarta

A. Sejarah Berdirinya Kabupaten

\section{Purwakarta}

Ketika Kabupaten Karawang diperintah oleh

bupati R.A. Suriawinata (1829-1849), ibukota kabupaten dipindahkan dari Wanayasa ke Sindangkasih ${ }^{3}$. Pada masa Hindia Belanda, perpindahan ibukota kabupaten bukan hal yang aneh, karena memang hal itu sering tejadi di beberapa daerah. Di Priangan misalnya, antara awal sampai dengan pertengahan abab ke-19, sejumlah kabupaten berulangkali mengalami perpindahan ibukota. Misalnya, tahun 1810 ibukota Kabupaten Bandung dipindahkan dari Krapyak (Dayeuhkolot sekarang) ke Kota Bandung yang didirikan pada tahun itu juga. Pada tahun yang sama, ibukota Kabupaten Parakanmuncang

\footnotetext{
${ }^{1}$ Pendirian pondok pesantren ini merupakan titik awal dari pendirian pondok pesantren lainnya yang ada di Purwakarta dengan menggunakan sistem pengajaran yang sama dengan Pondok Pesantren Sempur.

${ }^{2}$ Panggilan ini mengacu kepada nama pondok pesantren iitu sendiri dan juga nama daerah dimana pondok pesantren itu berdiri.

${ }^{3}$ Terdapat beberapa daerah yang bernama Sindangkasih, seperti di daerah Tasikmalaya (perbatasan dengan wilayah Kabupaten Ciamis), atau daerah Sindangkasih yang sekarang menjadi Kota Majalengka.
} 
dipindahkan ke Andawadak (kira-kira Tanjungsari, Sumedang sekarang). Tahun 1815 ibukota Kabupaten Galuh dipindahkan (perpindahan yang kedua kalinya) dari Imbanagara ke Cibatu (Ciamis). Tahun 1832 ibukota Kabupaten Sukapura dipindahkan dari Sukaraja ke Pasirpanjang (perpindahan ketiga kali), kemudian ke Manonjaya ${ }^{4}$. Pemindahan ibukota kabupaten pada dasarnya adalah inisiatif bupati yang bersangkutan.

Mengacu pada pemindahan ibukota kabupaten-kabupaten di Priangan, diduga pemindahan ibukota Kabupaten Karawang pun adalah gagasan bupati yang disetujui oleh asisten residen dan residen. Perpindahan ini tentu saja memiliki alasan dan tujuan. Dalam perpindahan ibukota kabupaten-kabupaten di Priangan, selain berdasarkan alasan yang sama, juga memiliki alasan yang berbeda. Akan tetapi, tujuan utama perpindahan itu sama. Demikian pula tujuan utama perpindahan ibukota Kabupaten Karawang ke Sindangkasih pada dasarnya sama dengan perpindahan ibukota beberapa kabupaten di Priangan, yaitu untuk kalancaran jalannya pemerintahan dan kemajuan kehidupan pemerintah serta masyarakatnya. ${ }^{5}$

4 A. Sobana Hardjasaputra (editor), Sejarah Purwakarta..., hlm. 42. Lihat pula Nina H Lubis, Sejarah Kota-Kota Lama di Jawa Barat, (Jatinangor: Alqaprint).

5 A. Sobana Hardjasaputra (editor), Sejarah Purwakarta..., hlm. 43.
Ibukota Kabupaten Karawang dipindahkan dari Wanayasa ke Sindangkasih berdasarkan dua alasan utama, alasan pertama adalah karena di daerah Wanayasa sering terjadi gangguan keamanan akibat ulah kelompok perampok, sedangkan alasan kedua dikarenakan kurang strategisnya daerah Wanayasa yang terletak di bagian selatan Karawang jika digunakan sebagai pusat pemerintahan. Perpindahan ibukota Kabupaten Karawang ke Sindangkasih ini diperkirakan terjadi pada tahun $1830 .{ }^{6}$

Proses perpindahan itu diawali oleh pencarian tempat yang dianggap baik untuk pusat pemerintahan kabupaten yang dilakukan oleh Bupati R.A. Suriawinata disertai oleh penasehatnya. Dalam upaya mencari tempat itu, bupati selalu meminta petunjuk dari Tuhan Yang Maha Kuasa melalui shalat istikharah. Beliau memang sangat taat menjalankan ajaran agama (Islam). Setiap waktu dan di setiap tempat, beliau selalu membaca solawat. Oleh karena itu, Bupati R.A. Suriawinata mendapat julukan "Dalem Solawat" dari masyarakat pribumi ketika itu. $^{7}$

Nama Sindangkasih memiliki makna yang mengacu pada arti kata sindang dan kasih. Dalam bahasa Sunda, sindang berarti

6 Djunaedi A. Sumantapura, Hari Jadi Purwakarta; dari Karawang ke Purwakarta Lewat Wanayasa, (Purwakarta: tp, 2002), hlm. 6.

${ }^{7}$ Uci Sanusi, Wawancara, tanggal 14 April 2017 di Purwakarta. 


\section{(Ulama Central dalam Islamisasi di Purwakarta)}

mampir atau singgah; kasih (dari kata asih) berarti sayang atau cinta (sunda: deudeuh, mikaresep) menurut cerita, ketika bupati R.A. Suriawinata beserta penasehatnya sampai ke tempat tersebut, mereka mampir di perkampungan untuk istirahat sejenak dari perjalanan yang sangat jauh dan lama. Penduduk setempat menyambut mereka dengan penuh hormat dan rasa kasih. Berdasarkan kejadian itu, timbullah keinginan untuk memberi nama kampung tersebut dengan nama Sindangkasih. ${ }^{8}$

Sindangkasih dipilih menjadi pusat pemerintahan Kabupaten Karawang menggantikan kedudukan Wanayasa, berdasarkan beberapa pertimbangan. Pertama, letak Sindangkasih cukup strategis bagi jalannya pemerintahan dikarenakan berada di bagian tengah daerah Karawang. Kedua, tanahnya subur dan arealnya memungkinkan untuk dikembangkan. Ketiga, memiliki sumber air, yaitu kubangan air yang kemudian dibangun menjadi Situ Buled $^{9}$. Keempat, memiliki suhu udara yang disenangi oleh para pejabat kolonial seperti residen dan asisten residen. Kelima, keberadaan Cikao sebagai pelabuhan sungai merupakan salah satu faktor penting bagi

8 Atoe Moehamad Natanagara, Sedjarah Purwakarta "Sepintas Kilas", (Purwakarta: Koleksi Pribadi Ahmad Said Widodo), hlm. 7.

${ }^{9}$ Sekarang menjadi objek wisata alam sesuai dengan peraturan daerah Kabupaten Purwakarta, No. 11 tahun 2012, tentang Rencana Tata Ruang Wilayah Kabupaten Purwakarta Tahun 2011-2031. kehidupan ekonomi masyarakat daerah setempat. ${ }^{10}$

Dengan kata lain kondisi Sindangkasih pada waktu itu dianggap lebih baik bila dibandingkan dengan kondisi Wanayasa. Pertimbangan-pertimbangan itu memang sesuai dengan tradisi masyarakat Sunda ketika itu dalam menentukan tempat untuk pusat pemerintahan. ${ }^{11}$ Menurut kepercayaan tradisional masyarakat Sunda, kondisi lahan yang baik untuk pusat pemerintahan harus seperti "Garuda ngupuk, bahé ngalérngétan, deukeut pangguyangan Badak putih". Makna ungkapan itu adalah letak dan kondisi lahan untuk ibukota harus baik dari berbagai segi serta dekat dengan sumber air. Kedudukan kota Purwakarta sendiri memiliki sejarah yang panjang dan kompleks. Seperti kita ketahui, pada awalnya Purwakarta berada di bawah wilayah Karawang, sedangkan Kabupaten Karawang sendiri berada di bawah pengaruh Mataram dan Kompeni (1620-1799). Hardjasaputra dalam bukunya menjelaskan, bahwa: ${ }^{12}$

Purwakarta sebelum menjadi kabupaten adalah bagian dari wilayah Kabupaten Karawang. Sejumlah sumber sejarah

${ }^{10}$ A. Sobana Hardjasaputra (editor), Sejarah Purwakarta..., hlm. 44.

${ }^{11}$ A. Sobana Hardjasaputra, Perubahan Sosial di Bandung 1810-1906, (Depok: UI, 2002), hlm. 27.

12 A. Sobana Hardjasaputra (editor), Sejarah Purwakarta..., hlm. 49. 


\section{Jurnal al-Tsaqafa Volume 15, No. 02, Desember 2018}

memuat data tentang Karawang menunjukkan, bahwa Purwakarta berasal dari Sindangkasih. Dengan kata lain, Sindangkasih adalah cikal bakal Purwakarta. Hal itu berarti, bagian awal perjalanan sejarah Sindangkasih (Purwakarta) adalah bagian dari sejarah Karawang.

Pada masa kolonial, dalam menjalankan pemerintahan di pusat kabupaten, bupati dibantu oleh sejumlah pejabat bawahannya, yaitu patih dalem dan patih luar, patinggi, hoofddjaksa (jaksa kepala), hoofdpenghulu (penghulu kepala), hoofdkommitter (komitir kepala), komitir urusan jalan, beberapa orang mantri, antara lain mantri gudang kopi, ngabehi, demang, lengser, dan lain-lain. Patih dan patinggi masing-masing memiliki sekretaris (juru tulis), yang mana mereka ini tinggal di ibukota kabupaten. ${ }^{13}$

Sejalan dengan berakhirnya kekuasaan Kompeni di Nusantara pada akhir tahun 1799 akibat VOC bangkrut, maka kekuasaan di Nusantara pun diambil alih oleh wakil pemerintah Prancis yang menduduki Belanda. Sejak itu pula terjadi perubahanperubahan kedudukan Karawang, mulai dari Karawang menjadi masuk ke daerah pedalaman Priangan (1808), lalu pada tahun

${ }^{13}$ A. Sobana Hardjasaputra, Perubahan Sosial..., hlm. 41-42.

${ }^{14}$ Proses pendirian Purwakarta sebagai ibukota Kabupaten Karawang, hampir sama dengan proses pendirian Kota Bandung yang diresmikan tanggal 25 September 1810, lihat dalam A. Sobana
1809 Karawang berubah menjadi Keresidenan Karawang, hingga pada masa Karawang diperintah oleh bupati R.A. Suriawinata (1829-1849) ibukota Karawang dipindahkan dari Wanayasa ke Sindangkasih (sekarang menjadi bagian dari Kabupaten Purwakarta) dan pada akhirnya Sindangkasih sebagai ibukota Kabupaten Karawang diresmikan berdasarkan besluit (surat keputusan) Pemerintah Kolonial tanggal 20 Juli 1831 nomor 2, dengan nama baru, yaitu Purwakarta ${ }^{14}$ yang dibangun di lahan kosong daerah Sindangkasih. Ketika Purwakarta diresmikan sebagai ibukota kabupaten, besar kemungkinan wilayah kota itu masih kecil dan dengan demikian, dapatlah dikatakan bahwa Sindangkasih adalah cikal-bakal Purwakarta.

Asal usul penamaan Purwakarta pun terdapat beberapa versi. Versi umum menyatakan nama itu diambil dari dua suku kata, yaitu purwa dan karta dalam bahasa Sansakerta. Purwa yang berarti awalan atau permulaan sedangkan karta memiliki arti aman tentram dan tertib atau ramai. ${ }^{15}$ Akan tetapi penjelasan mengenai arti kedua kata itu berbeda antara satu versi dengan versi lainnya. Versi lain menghubungkan kata itu dengan orang bernama Purbasari, salah

Hardjasaputra, Sejarah Kota Bandung 1810-1906, (Bandung: Lembaga Penelitian UNPAD, 1999).

15 Roesjan, Babad Purwakarta, (Bandung: Budaya Kalawarti, No. 14, Tahun 1956), hlm. 3. Lihat pula Ahmad Said Widodo, Sumber-Sumber Asli Sejarah Purwakarta, (Purwakarta, Jilid I, 2004). 
seorang penasehat atau kepercayaan Bupati R.A. Suriawinata yang memiliki peranan besar dalam mencari tempat untuk ibukota baru Kabupaten Karawang. Menurut versi itu, kata purwa berasal dari kata purba (purbakarta), yang merupakan nama bagian depan dari Purbasari dikarenakan menurut perasaannya, bahwa beliaulah yang pertama kali membangun tempat itu yang kemudian dirubah menjadi "Purwakarta". ${ }^{16}$ Adapun daerah Sindangkasih yang dijadikan sebagai cikal-bakal berdirinya Purwakarta sampai saat ini masih ada dan menjadi salah satu desa di Kabupaten Purwakarta.

Sebagai konsekuensi Purwakarta menjadi ibukota baru Kabupaten Karawang, pejabatpejabat bawahan bupati beserta asisten residen turut pindah dari Wanayasa ke Purwakarta. Dalam menjalankan tugas dan kewajibannya, para pejabat bawahan bupati dibantu pula oleh kepala cutak (kepala distrik) Sindangkasih dan kepala-kepala desa setempat. ${ }^{17}$

Setelah Bupati R.A. Suriawinata menetap di Sindangkasih, sebagian dari daerah itu segera dibangun menjadi ibukota baru Kabupaten Karawang dan dapat dipastikan bahwa pembangunan kota itu didasarkan pada pola kota tradisional, dengan ciri utama alun-alun sebagai pusat kota, pendopo di

16 Atoe Moehamad Natanagara, Sedjarah Purwakarta..., hlm. 7.

17 A. Sobana Hardjasaputra (editor), Sejarah Purwakarta..., hlm. 47. sebelah selatan alun-alun, masjid agung di sebelah barat dan rumah keluarga bupati di sebelah timur alun-alun. Pola kota dengan ciri-ciri tersebut memang merupakan pola kota-kota lama di Jawa Barat khususnya dan di Pulau Jawa pada umumnya.

Pada tahun 1928 Schakelschool mulai dibuka di Purwakarta. Murid pertama Schakeschool berjumlah 60 orang, diasuh oleh 2 orang guru. Pada akhir tahun 1920-an di Distrik Purwakarta terdapat satu sekolah gadis (Meisjeskopschool), 2 sekolah swasta, 1 sekolah Cina, sekolah agama Islam dengan sistem klasikal, sekolah khusus untuk golongan Arab dan 24 sekolah desa. Untuk mencukupi pengajar di sekolah desa, diselenggarakan kursus guru sekolah dasar. Salah satu tujuan pembukaan sekolah desa boleh jadi untuk menyekolahkan para kepala desa. Dikarenakan pada waktu itu sebagian besar kepala desa di Keresidenan Karawang masih buta huruf, sehingga mereka tidak mampu menjalankan pemerintahan desa dengan baik. ${ }^{18}$

Kabupaten Karawang dengan Ibukota Purwakarta berjalan sampai dengan tahun 1949. Pada tanggal 29 Januari 1949 dengan surat keputusan Wali Negeri Pasundan No. 12, Kabupaten Karawang dipecah menjadi dua, yakni Karawang Bagian Timur menjadi

18 A. Sobana Hardjasaputra (editor), Sejarah Purwakarta..., hlm. 77. 
Kabupaten Purwakarta dengan ibukota di Subang, sedangkan Karawang Bagian Barat menjadi Kabupaten Karawang. Berdasarkan UU No. 14 tahun 1950, tentang pembentukan daerah kabupaten dalam lingkungan Provinsi Jawa Barat, selanjutnya diatur penetapan Kabupaten Purwakarta, dengan ibukota di Purwakarta yang meliputi Kewedanaan Subang, Sagalaherang, Pamanukan, Ciasem dan Purwakarta. ${ }^{19}$

Pada tahun 1968, berdasarkan UU No. 4 tahun 1968 tentang pembentukan Kabupaten Purwakarta dan Kabupaten Subang Sk Wali Negeri Pasundan diubah dan ditetapkan pembentukan Kabupaten Purwakarta dengan Wilayah Kewedanaan Purwakarta ditambah dengan masing-masing dua desa dari Kabupaten Karawang dan Cianjur. Sehingga pada tahun 1968, Kabupaten Purwakarta hanya memiliki 4 kecamatan, di antaranya Kecamatan Purwakarta, Plered, Wanayasa dan Campaka dengan jumlah desa sebanyak 70 desa. Untuk mengisi kekosongan jabatan kepala daerah Kabupaten Purwakarta, R.H. Sunaryo Ronggowaluyo ditetapkan sebagai pejabat bupati Kabupaten Purwakarta. Dua minggu kemudian (12 Juli 1968), Menteri Dalam Negeri Letnan Jendral Basuki Rahmat meresmikan berdirinya Kabupaten Purwakarta dengan Ibukota Purwakarta dan

\footnotetext{
${ }^{19}$ Ucok Ujang Wardi, Wawancara, Tanggal 07 Maret 2018.
}

sekaligus melantik R.H. Sunaryo Ronggowaluyo menjadi Bupati Purwakarta. ${ }^{20}$

Berdasarkan perkembangan Kabupaten Purwakarta, pada tahun 1989 telah dikeluarkan Surat Keputusan Menteri Dalam Negeri Nomor: 821.26-672 tanggal 29 Agustus 1989 tentang lahirnya lembaga baru yang bernama wilayah kerja pembantu Bupati Purwakarta Wilayah Purwakarta yang meliputi wilayah Kecamatan Purwakarta, Kecamatan Jatiluhur, Kecamatan Campaka, perwakilan Kecamatan Cibungur yang pusat kedudukan pembantu Bupati Purwakarta berada di Purwakarta. Sedangkan wilayah kerja pembantu bupati Wilayah Plered meliputi wilayah Kecamatan Plered, Kecamatan Darangdan, Kecamatan Tegalwaru, Kecamatan Maniis, Kecamatan Sukatani yang pusat kedudukan pembantu Bupati Purwakarta berada di Plered. Wilayah kerja pembantu bupati Wilayah Wanayasa meliputi Kecamatan Wanayasa, Kecamatan Pasawahan, Kecamatan Bojong, perwakilan Kecamatan Kiarapedes, perwakilan Kecamatan Margasari dan perwakilan Kecamatan Parakansalam yang pusat kedudukan pembantu Bupati Purwakarta Wilayah Wanayasa berada di Wanayasa yang telah diresmikan pada tanggal 31

${ }^{20}$ Purwakarta Istimewa, (Bagian Humas dan Protokol Sekretariat Daerah Kabupaten Purwakarta, 2013), hlm. 9. 
Januari 1990 oleh Wakil Gubernur Jawa Barat. Setelah diberlakukannya UU No. 22 tahun 1999 tentang Pemerintahan Daerah, serta dimulainya pelaksanaan otonomi daerah di Kabupaten Purwakarta tepatnya pada tanggal 1 Januari 2001 serta memulai Peraturan Daerah No. 22 tahun 2001, telah terjadi restrukturisasi organisasi pemerintahan di Kabupaten Purwakarta. ${ }^{21}$

\section{B. Biografi dan Peran Baing Yusuf di}

\section{Purwakarta}

R.H.M. Yusuf atau yang kemudian lebih dikenal oleh masyarakat Purwakarta dengan sebutan Baing Yusuf merupakan penyebar agama Islam di wilayah Kabupaten Purwakarta $^{22}$, beliau dilahirkan di Bogor pada tahun $1709 \mathrm{M}$, merupakan keturunan langsung dari Keraton Padjadjaran. Nama baing sendiri merupakan sebutan untuk seorang yang dituakan (sesepuh), adapun menurut para ahli bahasa orang-orang jepang, baing sendiri merupakan satu tempat yang begitu mulia (menurut pandangan orang-orang tertentu secara keilmuan) ${ }^{23}$, dalam artian bahwa beliau merupakan seorang tokoh yang ditokohkan sehingga

21 Rahmi Rahmania, Peranan Syekh Baing Yusuf dalam Menyebarkan Agama Islam di Purwakarta 1828-1844, (Bandung: Universitas Pendidikan Indonesia, 2010), hlm. 73.

${ }^{22}$ Haji Umar dalam tulisannya yang berjudul Naskah Karawang nama Baing Yusuf adalah Raden Hadji Moehamad, sedangkan dalam catatan Belanda Almanak van Nederlandsch Indie Baing Yusuf bernama Raden Hadji Joesoef, jika kita pantas mendapatkan gelar baing di depan namanya.

Ketika masih kecil, beliau sudah menunjukkan tanda-tanda memiliki banyak kelebihan, usia 7 tahun sudah memahami bahasa Arab, usia 12 tahun sudah hafal alQur'an dan pada usia 13 tahun beliau pergi ke Mekkah selama 11 tahun. ${ }^{24}$ Beliau adalah salah seorang putra dari R. Aria Jayanegara yang pada waktu itu menjabat sebagai Bupati Bogor pada abad ke-17 dan makamnya sekarang berada di Kabupaten Karawang. Baing Yusuf sebenarnya merupakan keturunan Munding Sari alias Banjar Sari alias Sri Pamekas. Untuk lebih jelas, berikut adalah bagan silsilah keturunan Baing Yusuf.

menyimpulkan dari kedua sumber yang disebutkan di atas tadi, maka dapat ditarik kesimpulan bahwa nama Baing Yusuf adalah Raden Hadjie Moehamad Joesoef.

${ }^{23}$ Amal Saibiyan, Wawancara, tanggal 28 April 2017 di Purwakarta.

${ }^{24}$ Uci Sanusi, Wawancara, tanggal 14 April 2017 di Purwakarta. 


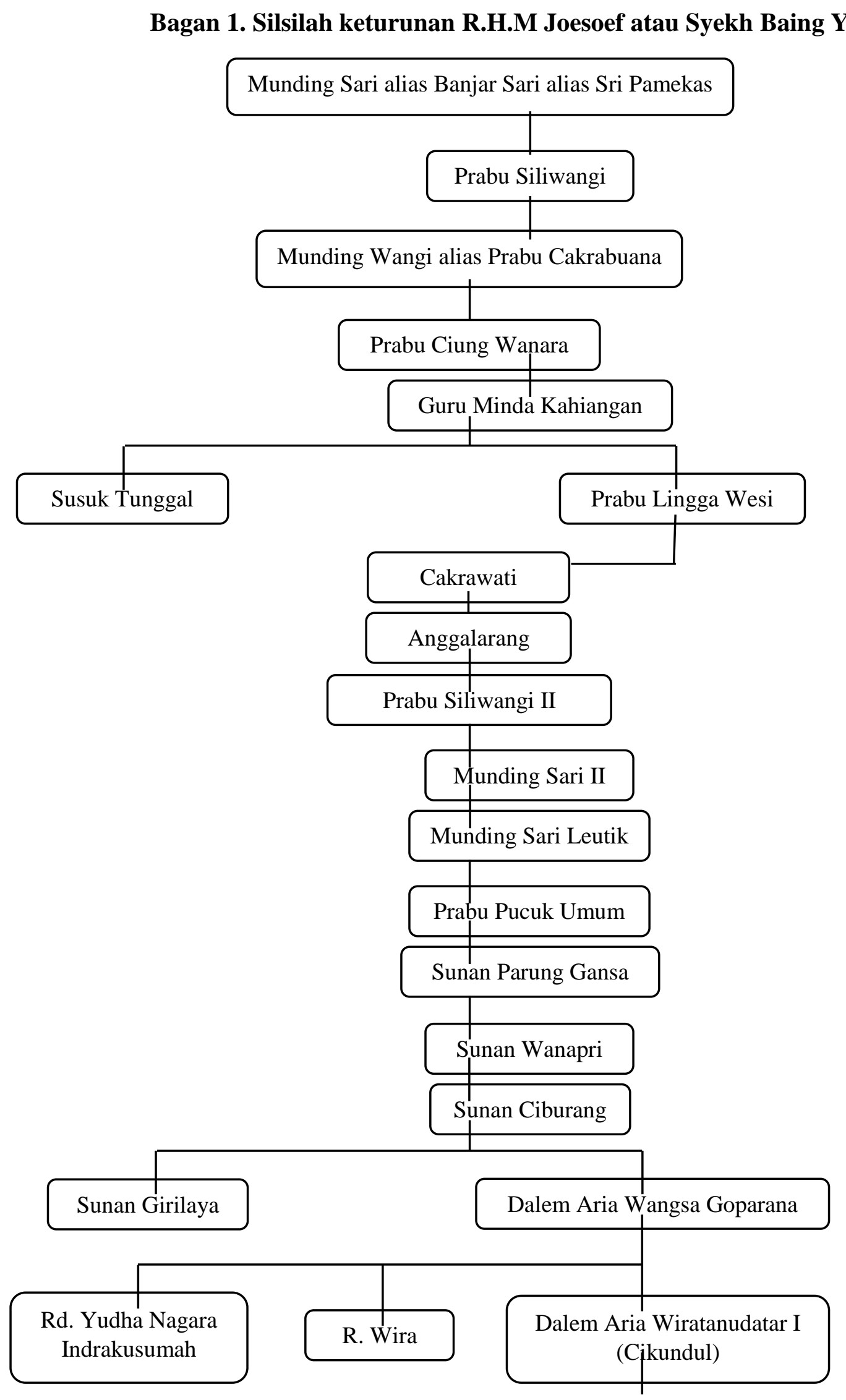

${ }^{25}$ Sanusi, Sejarah Singkat dan Bagan Silsilah Keturunan R.H.M Yoesoef, (Purwakarta: Karya Tulis Hasil Penelitian, Tanpa Tahun), hlm. 24-29. 


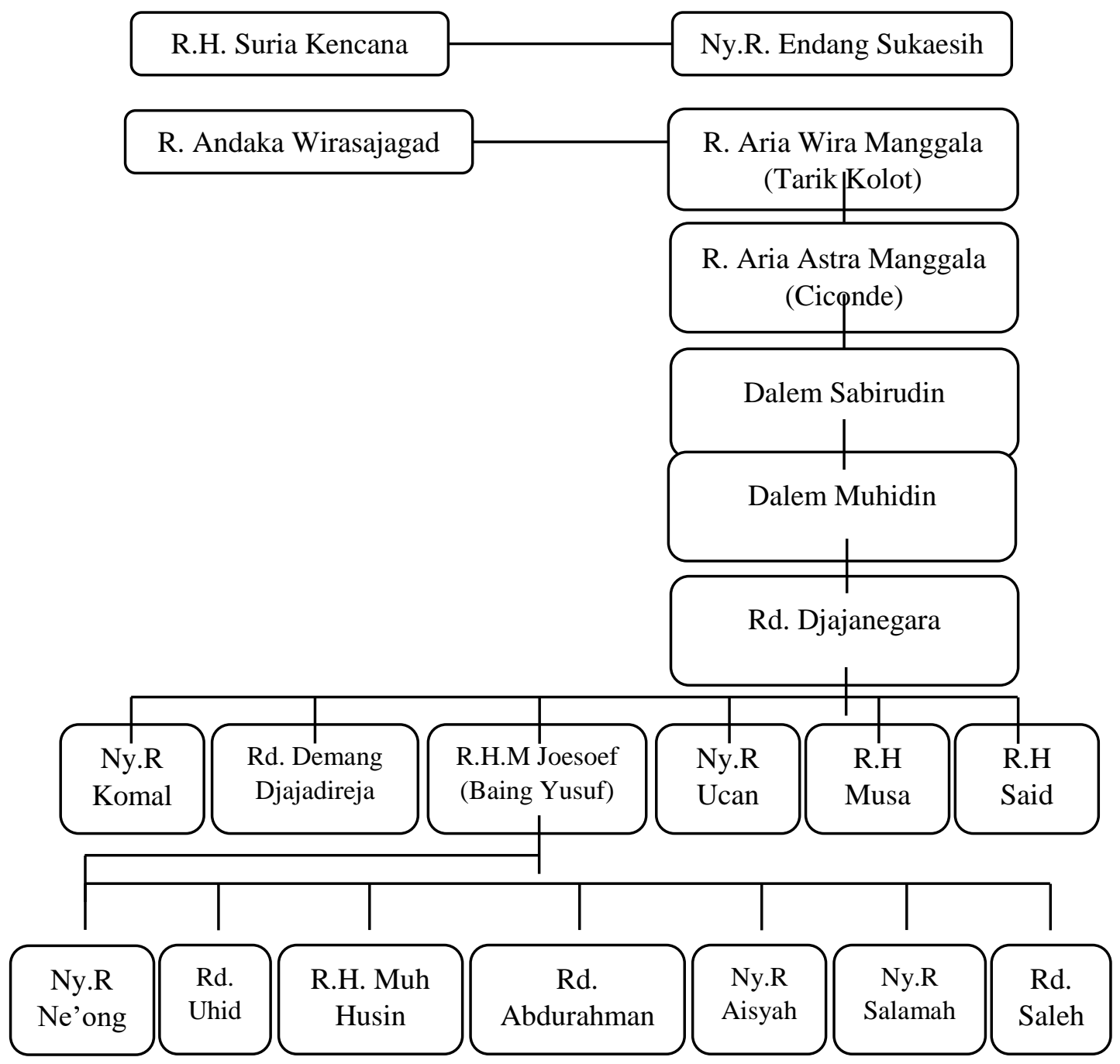

Dari bagan di atas, dapat disimpulkan bahwa

Baing Yusuf merupakan putra dari Rd. Aria Djajanegara dimana merupakan keturunan Dalem Muhiddin yang bila ditarik ke atas masih keturunan dari Prabu Siliwangi, sebagaimana yang telah diungkap oleh Sanusi dalam bukunya Sejarah Singkat dan Bagan Silsilah Keturunan R.H.M Yoesoef. Beliau mengambil sumber silsilah tersebut dari Museum Banjar dan Museum Banten.

Mengenai silsilah di atas, penulis sendiri masih meragukan kebenarannya, dikarenakan apakah silsilah itu memang benar dapat dipertanggungjawabkan atau hanya sebuah legitimasi guna mempermudah dalam proses penyebaran agama Islam yang terjadi di Purwakarta ketika itu serta memperkuat kedudukan beliau sebagai Hoofdpanghulu Karawang. Bahkan silsilah itu belum jelas siapa yang pertama kali membuatnya, apakah Baing Yusuf itu sendiri atau para pengikutnya guna membuat kebesaran nama Baing Yusuf akan terus diingat. Bahkan bisa saja Pemerintah Hindia Belanda memiliki andil yang sangat besar dalam membiasakan para calon 


\section{Jurnal al-Tsaqafa Volume 15, No. 02, Desember 2018}

pejabat untuk menjadi orang yang patronase. Hal itu dikarenakan Pemerintah Hindia Belanda menganggap penting peranan para elit politik pribumi dalam rangka pelaksanaan kebijakan pemerintah.

Selain ke Mekkah untuk melaksanakan ibadah haji, beliau juga pernah ke Madagaskar bersama para pelaut dari Nusantara. Sepulang dari pengembaraannya, beliau mengamalkan ilmu agama Islam yang didapatkannya dalam bentuk tulisan berupa buku, di antaranya adalah fiqh, tasawuf dan tauhid yang menggunakan bahasa Sunda. Guru beliau yang masyhur terutama terkenal adalah Syekh Cempaka Putih (Pengeran Diponegoro) ${ }^{26}$, sedangkan diantara muridnya yang paling terkenal adalah Syekh Nawawi al-Bantani yang meninggal di Mekkah dan dimakamkan di Ma'la. Buku karangan beliau masih ada sampai sekarang di salah satu universitas yang terdapat di Negara Amerika. ${ }^{27}$

Munculnya nama Syekh Nawawi al-Bantani dalam sejarah kehidupan Baing Yusuf hanya didapatkan dari cerita. Alkisah ketika itu, Syekh Nawawi al-Bantani menjadi seorang penghulu di Banten. Namun, meskipun kedudukannya sebagai penghulu, beliau dianggap masih belum pantas menjadi tokoh agama dikarenakan ilmunya yang masih

\footnotetext{
${ }^{26}$ Jika hal itu benar terjadi, maka dapat ditarik kesimpulan bahwa ketika Baing Yusuf belajar ke Syekh Campaka Putih, tokoh yang diidentikkan dengan Pangeran Diponegoro itu terjadi sebelum Baing Yusuf diangkat menjadi Hoofdpanghulu
}

kurang. Maka bergurulah ia ke Baing Yusuf yang ketika itu sudah tersohor ketinggian ilmunya. Pertemuannya dengan Baing Yusuf pun terjadi secara tidak sengaja. Ketika itu, beliau sedang berteduh di bawah pohon rindang karena sedang hujan lebat, disaat hujan mulai reda, Baing Yusuf mengingatkan kepada Syekh Nawawi alBantani bahwa pohon yang ia gunakan sebagai tempat berteduh adalah seekor ular besar, bukan pohon rindang seperti yang dipikirnya, sejak saat itulah Syekh Nawawi al-Bantani menjadi murid Baing Yusuf. Setelah itu, ia pergi ke Mekkah dan menjadi imam Masjidil Haram. Beliau adalah penulis kitab Safinah yang terkenal sampai saat ini dikalangan para santri di pondok pesantren. $^{28}$

Hal itu tidak dapat menjadi tolak ukur keberhasilan seorang Baing Yusuf yang telah melahirkan murid yang pada akhirnya memiliki nama besar dalam dunia Islam. Bisa saja hal itu merupakan legitimasi mengingat sumber yang membahas keterikatan Baing Yusuf dengan Syekh Nawawi al-Bantani belum ditemukan, akan tetapi menurut para narasumber sekaligus keturunan Baing Yusuf yang penulis wawancara menyebutkan bahwa Syekh Nawawi al-Bantani pernah nyantren (belajar

Karawang. Namun, data akurat yang menunjukkan kebenaran hal itu masih belum ditemukan.

${ }^{27}$ Sanusi, Sejarah Singkat..., hlm. 5.

${ }^{28}$ Rahmi Rahmania, Peranan Syekh Baing..., hlm. 81 . 
dan menjadi santri di pesantren yang didirikan oleh Baing Yusuf) di Purwakarta kepada Kyai Yusuf, seorang kyai terkenal yang menarik santri-santri dari daerahdaerah jauh di seluruh Jawa, terutama dari daerah Jawa Barat ketika itu.

Sebelum datangnya Baing Yusuf ke Karawang, masyarakat memang sudah memeluk agama Islam, akan tetapi masih belum menyeluruh. Akulturasi dengan kebudayaan Hindu masih tampak jelas dalam peribadatan mereka. Lalu, Baing Yusuf datang untuk menyempurnakan sesuai dengan pengetahuan yang telah beliau pelajari selama bertahun-tahun di Mekkah dan Madagaskar. Makna kata "menyempurnakan" disitu bukan berarti memberantas segala macam bentuk penyelewengan agama Islam dikarenakan ajaran Hindu masih membekas dalam kehidupan masyarakat ketika itu. Beliau sendiri masih menggunakan tradisi masyarakat untuk menarik simpati mereka, seperti yang dilakukan oleh para Wali dalam proses Islamisasi yang terjadi di Pulau Jawa. Baing Yusuf dalam menyebarkan agama Islam menggunakan corak keagamaan yang bertipe tradisional dan juga menggunakan metode dimana beliau melakukan silaturahmi ke rumah-rumah yang ada di

29 Naurid Ilyasa, Kyai "Sapu Pare” Baing Yusuf; Ulama Nu Ngabaladah Ngadegna Purwakarta, (Galura: Edisi 11 Juni 2017, No. 4), hlm. 8.

${ }^{30}$ Berdoa kepada Allah melalui suatu perantara, baik perantara tersebut berupa amal baik kita ataupun sekitaran itu. ${ }^{29}$ Religiusitas masyarakat Purwakarta saat ini merupakan hasil dari peranan yang dilakukan oleh Baing Yusuf, bahkan sampai sekarang masyarakat Purwakarta masih melaksanakan ajaranajaran yang diwariskan oleh Baing Yusuf. Salah satu ajaran Baing Yusuf yang masih sangat kuat tertanam dikalangan masyarakat Purwakarta adalah Tawassul ${ }^{30}$. Penulis sendiri sering menjumpai individu atau kelompok orang yang rutin melakukan wisata ziarah ke makam beliau atau makam tokoh-tokoh besar lainnya yang berpengaruh di daerah Purwakarta.

Baing Yusuf diangkat menjadi Hoofdpanghulu atas dasar pengetahuannya tentang agama Islam dan beliau juga merupakan keturunan Menak Sunda yang besar peranannya dalam mengembangkan agama Islam. ${ }^{31}$ Selain itu, Baing Yusuf juga memiliki kedekatan khusus dengan pihak kolonial. Hal tersebut dikarenakan sejak kecil beliau sudah dibiasakan oleh ayahnya untuk selalu bersikap baik kepada siapa pun. Alasan lainnya adalah Baing Yusuf merupakan sosok yang berkarismatik sehingga memudahkannya untuk dikenal oleh kalangan pemerintah kolonial. Baing Yusuf sebagai Hofdpanghulu Karawang dapat dipastikan kebenarannya dalam

melalui orang sholeh yang kita anggap mempunyai posisi lebih dekat kepada allah.

${ }^{31}$ Cardi Rukmana, Wawancara, Tanggal 09 Maret 2018. 


\section{Jurnal al-Tsaqafa Volume 15, No. 02, Desember 2018}

catatan Belanda Almanak van Nederlandsch Indie, tahun 1830an, No. 47-51.

Sebagai Hoofdpanghulu, Baing Yusuf berperan penting dalam proses pendirian Masjid Agung Purwakarta, dikarenakan pengelolaan Masjid Agung Purwakarta dan urusan keagamaan di pusat pemerintahan kabupaten menjadi tanggung jawab Hoofdpanghulu. Beliau menjabat sebagai Hoofdpanghulu selama kurang lebih 16 tahun (1828-1844). Almanak van Nederlandsch Indie, 1845 menyebutkan bahwa kedudukan Baing Yusuf sebagai Hoofdpanghulu digantikan oleh R. Moh. Husein. Adapun alasan Baing Yusuf melepaskan jabatannya sebagai Hoofdpanghulu masih belum diketahui, mungkin beliau dipensiunkan atau bisa jadi beliau meminta pensiun karena usia tua. Karena ketika Baing Yusuf melepaskan jabatannya, beliau sudah mencapai usia lanjut, yaitu sekitar 135 tahun.

Selain menjalankan tugasnya sebagai Hoofdpanghulu, Baing Yusuf juga ikut membantu Pemerintah Kolonial dalam menjaga keamanan dan ketentraman rakyat. Hal itu tercermin dari keikutsertaannya dalam memberantas pemberontakan Cina Makao yang terjadi di Rancadarah yang kemudian lebih dikenal dengan peristiwa

${ }^{32}$ Naurid Ilyasa, Kyai “Sapu Pare..., hlm. 8.

${ }^{33}$ Kejadian ini diceritakan dalam buku karangan R. Suriadireja yang berjudul Campaka Warna yang ditulis dengan aksara Hanacaraka Sunda dengan gaya
Perang Makao. Perang ini menyisakan cerita tersendiri mengenai keterlibatan Baing Yusuf dalam memberantas para pengacau, beliau terkenal dengan "sapu pare" yang dinyalakannya, dimana ketika beliau menyalakan sapu lidi yang kelihatan oleh orang-orang Cina Makao tampak seperti pasukan yang beribu-ribu banyaknya. ${ }^{32}$ Orang-orang Cina Makao itu datang dari daerah Makao (Cina Selatan) yang masuk ke Indonesia melalu Batavia (Jakarta). Setelah mengacau di Batavia mereka kemudian lari ke Karawang hingga berakhir di daerah Cilangkap. Disana mereka mulai membuka hutan yang kemudian mereka bersama dengan pelarian dari penjara Purwakarta merampok dan membakar rumah-rumah penduduk. Kerusuhan itu terjadi pada tahun 1832 yang dilakukan oleh orang-orang Cina Makao, dimana mereka mengganggu keamanan, merampok dan membakar rumah-rumah penduduk. ${ }^{33}$

Kurang lebih selama dua dasawarsa, Baing Yusuf menjadi Hoofdpanghulu. Beliau banyak memberikan konstribusi pikiran dan tenaga, baik itu kepada pemerintah Kabupaten Purwakarta maupun kepada masyarakat Purwakarta. Baing Yusuf juga merupakan tokoh yang berperan penting dalam menata dan mengembangkan

tulisan Pupuh Sunda dan diterbitkan pada tahun 1932 sampai 1938 M. Juga dalam Babad Purwakarta tulisan Roesjan yang berbahasa Sunda (Dokumen Pribadi Ahmad Said Widodo). 
kehidupan agama Islam di Purwakarta.

Setelah berhenti sebagai Hoofdpanghulu, beliau mencurahkan perhatiannya pada pengelolaan pesantren khususnya dan membina masyarakat pada umumnya dalam kehidupan beragama, bahkan hal itu dilakukan oleh Baing Yusuf sampai meninggal dunia.

Terdapat dua versi mengenai tahun kematian Baing Yusuf, versi pertama beliau meninggal pada tahun 1854, sedangkan versi kedua terjadi pada tahun 1856. Versi pertama mengenai kematian Baing Yusuf terdapat dalam buku karangan Sanusi yang berjudul Sejarah Singkat dan Bagan Silsilah Keturunan R.H.M. Yoesoef, sedangkan untuk versi kedua terdapat dalam buku yang berjudul Sejarah Purwakarta (1633-1942): Dari Karawang ke Purwakarta Lewat Wanayasa yang ditulis oleh Sumantapura. Jika berbicara mengenai tahun mana yang benar, sampai saat ini belum dapat dipastikan dan tentu saja masih memerlukan penelitian yang lebih mendalam lagi, akan tetapi di situs makam Baing Yusuf tercantum tahun 1856. Berangkat dari bukti itulah, maka di sini penulis lebih condong pada versi yang kedua.

Makam beliau terdapat di belakang Masjid Agung Purwakarta bersama dengan makam para bupati Karawang di Purwakarta dan keluarganya, seperti R. Rasmitungrat, R. Aju Haditungrat, R.A.A. Sastrawinata dan lain- lain. Sampai sekarang makamnya sering dikunjungi oleh orang-orang dari daerah Jawa Barat khususnya dan dari luar Jawa Barat pada umumnya untuk melakukan ziarah kubur.

Meskipun Baing Yusuf memiliki peranan yang sangat besar dalam penyebaran sekaligus pengembangan agama Islam di Purwakarta, sangat disayangkan bahwa masyarakat Purwakarta ada yang tidak mengenal akan sosok beliau dan bahkan tidak banyak yang mengetahui mengenai perjuangan Baing Yusuf dalam menyebarkan agama Islam di Purwakarta. Pihak pemerintah pun sepertinya kurang memberikan perhatian terhadap sejarah perkembangan agama Islam di Purwakarta pada umumnya dan peranan Baing Yusuf pada khususnya. Dimana hal itu terbukti dengan minimnya sumber-sumber sejarah yang berkaitan dengan tema-tema yang disebutkan di atas tadi.

\section{PENUTUP}

Sejarah lahirnya Kota Purwakarta tidak dapat dipisahkan keberadaannya dengan Kabupaten Karawang. Dulu ibukota Kabupaten Karawang berada di Wanayasa, akan tetapi ibukota kembali dipindahkan ke Sindangkasih oleh bupati ketika itu atas persetujuan dari pemerintah kolonial, hal itu terjadi dikarenakan di daerah Wanayasa sering terjadi gangguan keamanan dan 
kurang strategisnya daerah itu jika digunakan sebagai pusat pemerintahan, perpindahan ibukota ini diperkirakan terjadi pada tahun 1830. Sindangkasih dalam perjalanannya berganti nama menjadi Purwakarta, ketika Purwakarta diresmikan sebagai Ibukota Karawang besar kemungkinan wilayah ini masih kecil. Sebagai konsekuensi Purwakarta menjadi ibukota Kabupaten Karawang, pejabatpejabat bawahan bupati beserta asisten residen turut pindah dari Wanayasa ke Purwakarta. Kabupaten Karawang dengan Ibukota Purwakarta berjalan sampai dengan tahun 1949. Pada tanggal 29 Januari 1949 Kabupaten Karawang dipecah menjadi dua, yakni Karawang bagian timur menjadi Kabupaten Purwakarta dan Karawang bagian barat menjadi Kabupaten Karawang. R.H.M Yusuf atau lebih dikenal dengan nama Baing Yusuf merupakan seorang ulama yang memiliki peranan dalam penyebaran agama Islam di Purwakarta, beliau ketika masih kecil sudah menunjukkan tanda-tanda kelebihan. Usia 7 tahun sudah memahami Bahasa Arab, usia 12 tahun sudah hafal al-Qur'an dan pada usia 13 tahun beliau pergi ke Mekkah selama 11 tahun. Sebagai kepala penghulu, Baing Yusuf berperan penting dalam proses pendirian masjid agung karena pengelolaan masjid dan urusan keagamaan di pusat pemerintahan kabupaten menjadi tanggung jawab kepala penghulu. Dalam menyebarkan agama Islam di Purwakarta, beliau menggunakan corak keagamaan yang bertipe tradisional dan juga menggunakan metode dimana beliau melakukan silaturahmi ke rumah-rumah yang ada di sekitaran itu. Beliau meninggal pada tahun 1856 hal itu dapat dilihat pada situs makam beliau yang terletak di belakang Masjid Agung Baing Yusuf.

\section{DAFTAR SUMBER \\ 1. Sumber Tertulis \\ a. Arsip/Dokumen}

Almanak van Nederlandsch Indie Voor Het Jaan 1830, Purwakarta: koleksi pribadi Ahmad Said Widodo). tentang daftar nama orang-orang yang masuk ke dalam struktur Pemerintahan Kolonial Belanda, seperti Assistent Resident, Hoofd Jaksa, Hoofd Panghoeloe dan lain sebagainya.

Bisluit dari Gubernur Jenderal Hindia Belanda, 20 Juli 1831 No. 2 (koleksi pribadi Ahmad Said Widodo). tentang perubahan nama ibukota Afdeeling Krawang menjadi Purwakarta.

Haji Umar, Tanpa Tahun, "Naskah Krawang”, Purwakarta: koleksi pribadi Ahmad Said Widodo.

Lembaran Negara Republik Indonesia, No. 31 tahun 1968, Purwakarta: koleksi pribadi Ahmad Said Widodo.

Peraturan Daerah Kabupaten Purwakarta, No. 11 tahun 2012 tentang rencana tata 
ruang wilayah Kabupaten Purwakarta tahun 2011-2031.

Surat dari Asisten Residen Karawang, 20 Juli 1831 (Koleksi Pribadi Ahmad Said Widodo).

Tanda tangan Johannes van Den Bosch mengenai Besluit No. 2, (koleksi pribadi Ahmad Said Widodo).

Undang-undang Republik Indonesia, No. 4 tahun 1968 tentang pembentukan Kabupaten Purwakarta dan Kabupaten Subang.

b. Artikel, Buku, Naskah Terpublikasi Nina H Lubis, Sejarah Kota-Kota Lama di Jawa Barat, Jatinangor: Alqaprint.

Sobana Hardjasaputra, 2002, Perubahan Sosial di Bandung 1810-1906, Disertasi, Depok: Program Pasca Sarjana Fakultas Sastra UI. 1999, Sejarah Kota

Bandung 1810-1906, Bandung: Universitas Padjajaran.

2004, Sejarah

Purwakarta, Purwakarta: Pemerintah

Kabupaten Purwakarta.

Sumantapura Djunaedi A, 1999, Sejarah

Purwakarta (1633-1942); Dari Karawang

ke Purwakarta Lewat Wanayasa,

Purwakarta: DHC Angkatan 45 Kab.

Purwakarta.

2002, Hari Jadi

Purwakarta; Dari Karawang ke Purwakarta

Lewat Wanayasa, Purwakarta: tp.

c. Jurnal, Majalah dan Surat Kabar
Ahmad Said Widodo, 2004, "Sumbersumber Asli Sejarah Purwakarta", Karya Tulis Hasil Penelitian, Purwakarta.

Atoe Moehamad Natanagara, Sedjarah Purwakarta "Sepintas Kilas”, Purwakarta: Koleksi Pribadi Ahmad Said Widodo.

Naurid Ilyasa, 2017, “Kyai Sapu Pare Baing Yusuf; Ulama $\mathrm{Nu}$ Ngabaladah Ngadegna Purwakarta", Koran Galura, Edisi 11 Juni 2017, No. 4, hlm. 8.

Rahmi Rahmania, 2010, "Peranan Syekh Baing Yusuf dalam Menyebarkan Agama Islam di Purwakarta 1828-1844", Skripsi, Bandung: Universitas Pendidikan Indonesia. Roesjan, "Babad Purwakarta", Koleksi Pribadi Ahmad Said Widodo, Bandung: Budaya Kalawarti, No. 14, Tahun 1956. Sanusi, Tanpa Tahun, "Sejarah Singkat dan Bagan Silsilah Keturunan R. H. M. Yoesoef", Karya Tulis Hasil Penelitian, Purwakarta.

\section{Sumber Lisan}

Amal Sibyan (65 tahun), Keturunan dari R.H.M Yoesoef, Wawancara, Kantor Arsip Kabupaten Purwakarta, tanggal 21 April 2017.

Cardi Rukmana (48 tahun), Eks Kuwu atau Kades, Wawancara, Mesjid Agung Baing Yusuf, tanggal 09 Maret 2018.

R. H. Sanusi AS (67 tahun). Bidang Imarah Masjid Agung Baing Yusuf. Wawancara. Purwakarta, tanggal 14 April 2017. 
Jurnal al-Tsaqafa Volume 15, No. 02, Desember 2018

Ucok Ujang Wardi, S.H (47 tahun), Birokrat

atau Mantan Ketua DPRD Kab. Purwakarta,

Wawancara, Kantor DPD Golkar Kab.

Purwakarta, tanggal 07 Maret 2018. 